02

\title{
Люминесцентные свойства разнолигандных $\beta$-дикетонатов неодима, полученных в среде сверхкритического диоксида углерода в полимерных матрицах различной природы
}

\author{
(C) В.С. Каплин ${ }^{1}$, А.С. Копылов ${ }^{1}$, Т.С. Зархина ${ }^{1}$, П.С. Тимашев ${ }^{1,2,3}$, А.Б. Соловьева ${ }^{1}$ \\ ${ }^{1}$ Федеральный исследовательский центр химической физики РАН им. Н.Н. Семёнова, \\ 119991 Москва, Россия \\ ${ }^{2}$ ИФТ РАН, ФНИЦ „Кристаллографрия и фоотоника“ РАН, \\ 108840 Троицк, Москва, Россия \\ ${ }^{3}$ Институт регенеративной медицины, Первый МГМУ им. И. М. Сеченова, \\ 119048 Москва, Россия \\ e-mail: piroklas@gmail.com
}

Поступила в редакцию 20.12.2019 г.

В окончательной редакции 02.02.2020 г.

Принята к публикации 28.02.2020 г.

\begin{abstract}
Разнолигандные люминофорные комплексы ацетилацетоната неодима с фенантролином синтезированы в матрицах полимеров (олигоуретанметакрилат, фторопласт, поликарбонат) в среде сверхкритического диоксида углерода, при этом роль одного из лигандов в таких комплексах выполняют фрагменты полимерной матрицы. Описаны спектры люминесценции полученных тройных систем, при этом показано, что положение максимумов люминесценции батохромно смещено относительно двойных систем $\mathrm{Nd}(\mathrm{Acac})_{3} /$ полимер, полученных аналогичным способом, а величина сдвига зависит от природы полимерной матрицы. Показано, что при введении этих компонентов в полимеры из раствора подобные люминофорные разнолигандные комплексы неодима не образуются. Методом дифференциально-термического анализа подтверждено формирование новых структур $\mathrm{Nd}(\mathrm{Acac})_{3} / \mathrm{Phen} /$ полимер при импрегнации олигоуретанметакрилата $\beta$-дикетонатом неодима и фенантролином в среде сверхкритического $\mathrm{CO}_{2}$, не образующихся при введении этих компонентов из раствора.
\end{abstract}

Ключевые слова: люминесценция, ацетилацетонат неодима, фенантролин, разнолигандные $\beta$-дикетонаты, сверхкритический диоксид углерода.

DOI: $10.21883 /$ OS.2020.07.49555.30-20

\section{Введение}

Наличие интенсивной люминесценции у комплексов редкоземельных элементов (РЗЭ), в частности у $\beta$-дикетонатов, позволяет использовать их при получении люминесцентных полимерных материалов различного назначения: оптоволоконных волноводов, OLED, оптических сенсоров, конвертеров солнечной энергии [1-5]. Органические комплексы РЗЭ обладают большим сродством к полимерам, чем неорганические люминофоры, а также эффективно преобразуют поглощаемую энергию света в узкополосное люминесцентное излучение через механизм сенсибилизации лиганда [6].

Одной из проблем, возникающих при получении полимеров, допированных металлокомплексами, является гомогенность и равномерность распределения их в полимерной матрице, обеспечивающая высокую эффективность преобразования УФ излучения. Одним из методов получения полимеров, обеспечивающих гомогенность распределения РЗЭ, является соответствующая модификация мономеров с последующей их гомо- или сополимеризацией [7]. Однако процесс полимеризации (выбор метода и инициирующего воздействия) довольно сложен и должен проводиться с учётом специфики строения и свойств металлсодержащих мономеров [8]. Также гомогенность распределения люминофорных комплексов РЗЭ обеспечивает использование „растворного метода“ (совместное растворение полимера и люминофора в подходящем растворителе) [9] или метода „пропитки“ (т.е. набухания полимерной матрицы в органических растворителях, содержащих комплексы РЗЭ). Однако использование этих способов ограничивается небольшим числом полимеров, способных к набуханию или растворению в органических растворителях [10].

Ранее нами было установлено, что методом сверхкритической (ск) импрегнации полимеров удаётся получить люминофорные полимерные материалы, содержащие $\mathrm{Nd}(\mathrm{Acac})_{3}$. Характер люминесценции $\mathrm{Nd}(\mathrm{Acac})_{3}$, введённого таким образом в полимерные матрицы (олигоуретанметакрилат, фторопласт, поликарбонат), меняется относительно его люминесценции в растворе: наблюдается уширение полос люминесценции и ухудшение их разрешения [11]. Такое изменение ширины полос люминесценции может быть вызвано взаимодействием комплекса в среде ск-флюида с фрагментами полимерной матрицы, которые могут рассматриваться как дополнительные лиганды. При этом интенсивность 
люминесценции образующихся систем была невысока. Поскольку возбуждение центрального иона металла в $\beta$-дикетонатах РЗЭ происходит посредством переноса энергии на центральный ион от лигандного окружения, введение дополнительных лигандов используется для варьирования положения энергетических уровней комплекса и интенсивности флуоресценции, а также некоторых физико-химических характеристик люминофора - растворимости и летучести [12]. В качестве дополнительного лиганда, повышающего квантовый выход и эффективность сенсибилизации фотолюминесценции в комплексах РЗЭ, обычно используют 1,10-фенантролин (Phen) [13], обладающий большой поглощательной способностью, быстрой интеркомбинационной конверсией и эффективным переносом энергии на центральный ион [14]. Кроме того, введение фенантролина повышает интенсивность флуоресценции $\beta$-дикетонатов Р3Э благодаря исключению основного пути безызлучательной диссипации энергии через колебания окружающих ион $\operatorname{Ln}(\mathrm{III})$ молекул. Взаимодействие с молекулами воды во внешней координационной сфере комплекса приводит к потере значительной части поглощённой энергии на возбуждение высокочастотных колебаний групп О-H $\left(3600 \mathrm{~cm}^{-1}\right)$ и к её последующей безызлучательной релаксации [15]. Введение молекул фенантролина приводит к замещению молекул воды во внешней координационной сфере и уменьшению энергии колебаний окружающих ион групп [16]. В данной работе в среде ск- $\mathrm{CO}_{2}$ осуществлена импрегнация ряда полимеров (олигоуретанметакрилат, фторопласт, поликарбонат) смешанным комплексом $\mathrm{Nd}(\mathrm{Acac})_{3}$ с фенантролином. При этом образование комплекса происходило непосредственно в полимерной матрице, причём фрагменты макромолекул, очевидно, участвовали в стабилизации системы. Использование в качестве растворителя ск- $\mathrm{CO}_{2}$, в котором практически отсутствует эффект сольватации, позволило осуществить этот процесс.

\section{Экспериментальная часть}

\section{Реактивы и материалы}

Использовали ацетилацетонат неодима (III) в виде кристаллогидрата $\left(\mathrm{Nd}(\mathrm{Acac})_{3} \cdot n \mathrm{H}_{2} \mathrm{O}\right)$ (Aldrich), 1,10фенантролин кристаллический (Acros Organics 99+\%) (Phen), двуокись углерода (ООО „НИИ КМ“ 99.8\% ГОСТ 8050-85).

В работе использовали следующие полимеры в виде оптически прозрачных плёнок:

- олигоуретанметакрилат (ОУМ-5, синтезирован в лаборатории № 1623 ФИЦ ХФ РАН (А.В. Котова, Н.Н. Глаголев, И.А. Матвеева и др. // ВМС. А. 2010. T. 52. С. 805), толщина плёнки $900 \mu \mathrm{m})$;

- поликарбонат LEXAN 8010 (SABIC Innovative Plastics, толщина плёнки $375 \mu \mathrm{m})$;
- сополимер винилиденфторида и тетрафторэтилена (2:1), Ф-42 (марка В, ГОСТ 25428-82), получен испарением раствора в ацетоне, толщина плёнки 345-405 $\mu \mathrm{m}$.

Проведена серия опытов по ск-импрегнации исходных полимеров (ОУМ-5, Ф-42 и ПК) комплексом $\mathrm{Nd}(\mathrm{Acac})_{3}$ и фенантролином. В том числе проведена ск-импрегнация полимеров: сначала полимеры пропитывались в ск-среде $\mathrm{Nd}(\mathrm{Acac})_{3}$, затем регистрировались спектры люминесценции полученных образцов, после чего проводилась повторная ск-пропитка молекулами фенантролина. Навески $\mathrm{Nd}(\mathrm{Acac})_{3}$ в опытах - $100 \mathrm{mg}$. Навески фенантролина в опытах - $20 \mathrm{mg}$. Массы импрегнируемых образцов варьировались от 50 до $150 \mathrm{mg}$. Методика и условия процесса СКФ-импрегнации были описаны в [11]. Для пропитки полимеров $\mathrm{Nd}(\mathrm{Acac})_{3}$ и фенантролином „растворным методом“ полимеры в течение $22 \mathrm{~h}$ выдерживались в смеси ацетон/хлороформ в объёмном соотношении $13: 8$, содержание в растворах $\mathrm{Nd}(\text { Acac })_{3}$ и Phen $1.2 \cdot 10^{-3}$ М. При данном соотношении растворителей все три исследуемых полимера (ОУМ-5, Ф-42, ПК) набухают без разрушения. Набухаемость оценивали сопоставлением линейных размеров плёнок до пропитки и сразу после извлечения плёнок из раствора. Для ОУМ-5 и Ф-42 она составила около $20 \%$, для ПК около $5 \%$.

\section{Методы исследования}

Спектры люминесценции растворов и плёнок регистрировались с использованием спектрофлуориметра Shimadzu RF-5301PC. Почти все спектры люминесценции были представлены широкими полосами, образованными наложением нескольких более узких полос, поэтому спектры раскладывали на составляющие компоненты в программе Origin 7.0.

Дифференциальный термический анализ (ДТА) образцов проводили на синхронном термоанализаторе STA 449 F3 фирмы NETZSCH. Навески образцов составляли 10-12 mg. Процесс деструкции полимеров проводили на воздухе при скорости потока газа $30 \mathrm{ml} / \mathrm{min}$ и линейной скорости нагрева $10^{\circ} \mathrm{C} / \mathrm{min}$. Изменения потери массы регистрировались с точностью до $10^{-3} \mathrm{mg}$, относительная погрешность измерения температуры составляла $\pm 1.5^{\circ} \mathrm{C}$, тепловых эффектов $- \pm 3 \%$.

Процесс термоокислительной деструкции (ТОД) описывали зависимостями потери массы (ТГ), скорости потери массы (ДТГ) и тепловых эффектов (ДСК) от температуры. В качестве параметров, характеризующих деструкцию, были выбраны: по кривым ТГ - температура стадийности $\left(,{ }^{\circ} \mathrm{C}\right)$ процесса потери массы, потеря массы в основной стадии $(\Delta m, \%)$ и коксовый остаток $(\%)$, по кривым ДТГ - максимальная скорость потери массы $\left(W_{\max }, \% / \mathrm{min}\right)$, по кривым ДТА - величины тепловых потоков, сопровождающих стадии потери массы $(Q, \mathrm{~J} / \mathrm{g})$. 
Таблица 1. Характерные максимумы полос люминесценции $\mathrm{Nd}(\mathrm{Acac})_{3}$, Phen и $\mathrm{Nd}(\mathrm{Acac})_{3}$ с Phen, введённых в среде ск-CO полимеры, а также $\mathrm{Nd}(\mathrm{Acac})_{3}$ и фенантролина в совместном растворе в хлороформе. Положение наиболее интенсивных полос люминесценции выделено жирным

\begin{tabular}{|c|c|c|c|c|}
\hline \multirow{2}{*}{$\begin{array}{l}\text { Растворенное } \\
\text { вещество }\end{array}$} & \multicolumn{4}{|c|}{$\begin{array}{l}\text { Положения максимумов полос люминесценции } \\
\text { ск-импрегнированных полимеров и растворов, } \mathrm{nm}\end{array}$} \\
\hline & Раствор в хлороформе & OУМ-5 & $\Phi-42$ & ПК \\
\hline $\mathrm{Nd}(\text { Acac })_{3}$ & $413,437,462,487$ & $418,448,472,512$ & $393, \mathbf{4 3 2}, 461,514$ & $417, \mathbf{4 3 0}, 460$ \\
\hline Фенантролин & - & 440,505 & 451,507 & 428,463 \\
\hline $\mathrm{Nd}(\mathrm{Acac})_{3}$ и Phen & $383,405,425,444,476$ & 496,546 & 453,520 & 422,456 \\
\hline $\begin{array}{l}\text { Экстракт ОУМ-5, } \\
\text { ск-импрегнированной } \\
\text { Nd(Acac) })_{3} \text { и Phen }\end{array}$ & $404,427,445,468$ & & - & \\
\hline
\end{tabular}

\section{Обсуждение результатов}

\section{Люминесцентные свойства полимеров, содержащих $\mathrm{Nd}(\mathrm{Acac})_{3}$ и фенантролин}

Как уже упоминалось, введение в комплекс $\mathrm{Nd}(\text { Acac })_{3}$ дополнительного лиганда - фенантролина может способствовать снижению вероятности тушения люминесценции молекулами воды [15] во внешней координационной сфере комплекса, а также повышению эффективности сенсибилизации центрального атома (т.е. повышению интенсивности люминесценции).

\section{Природа люминесценции полимеров, ск-импре-} гнированных $\mathrm{Nd}(\mathrm{Acac})_{3}$ и фенантролином. На рис. 1 приведены спектры флуоресценции, а в табл. 1 соответствующие положения полос ацетилацетоната неодима и фенантролина в растворе и образцов полимеров (ОУМ-5, Ф-42 и ПК), содержащих введённый в среде ск- $\mathrm{CO}_{2}$ ацетилацетонат неодима и фенантролин, а также полимеров, ск-импрегнированных обоими соединениями. Видно (рис. 1,, , табл. 1), что в спектрах образцов ОУМ-5, Ф-42 и ПК, содержащих Phen, присутствуют малоинтенсивные широкие полосы люминесценции с максимумами около $450 \mathrm{~nm}$. Поскольку фенантролин в растворах не обладает люминофорными свойствами, можно полагать, что при введении в среде ск- $\mathrm{CO}_{2}$ в используемые полимеры Phen может образовывать с донорно-акцепторными группировками макромолекул слабосвязанные комплексы, что приводит к появлению у него интенсивной люминесценции в соответствующих матрицах.

В спектрах люминесценции образцов, содержащих $\mathrm{Nd}(\mathrm{Acac})_{3}$ и Phen (рис. 1,d,e,i), зафиксировано батохромное смещение максимумов относительно максимумов люминесценции систем $\mathrm{Nd}(\mathrm{Acac})_{3} /$ полимер и Phen/полимер [11], что, очевидно, означает образование смешанного $\beta$-дикетоната неодима $\mathrm{Nd}(\mathrm{Acac})_{3}$ (Phen), стабилизированного слабыми взаимодействиями с фрагментами макромолекул носителя. Об этом свидетельствует разрушение комплекса при вымывании из сшитой полимерной матрицы ОУМ-5 в хлороформ и отсутствие прямых взаимодействий в растворах сольватированного Phen, $\mathrm{Nd}(\mathrm{Acac})_{3}$ и полимерных молекул.

Наибольшая величина сдвига зафиксирована для системы $\mathrm{Nd}(\mathrm{Acac})_{3}$ (Phen)/OУМ-5: границы широкой полосы люминесценции, очевидно образующейся наложением нескольких узких полос, смещаются на величину около $80 \mathrm{~nm}$. Следующий по величине сдвиг наблюдается для $\Phi-42-30 \mathrm{~nm}$. Широкая полоса люминесценции $\mathrm{Nd}(\mathrm{Acac})_{3}$ в этом полимере имеет максимум около $430 \mathrm{~nm}$, а также хорошо выраженное плечо в области $520 \mathrm{~nm}$. После импрегнации таких образцов фенантролином границы люминесценции, как следует из данных табл. 1, также претерпевают батохромный сдвиг. Причём широкая полоса с максимумом около $460 \mathrm{~nm}$ может относиться как к люминесценции новообразовавшейся системы $\mathrm{Nd}(\mathrm{Acac})_{3} / \mathrm{Phen} /$ полимер, так и к люминесценции молекул фенантролина, не принявших участия в образовании этой системы, так как положение её максимума совпадает с максимумом люминесценции полимеров, импрегнированных одним фенантролином. Однако аналогичное смещение плеча, относящегося к люминесценции комплекса неодима $(520 \mathrm{~nm})$ до $\sim 545 \mathrm{~nm}$ очевидно свидетельствует об образовании новых центров люминесценции. В матрице поликарбоната положение максимумов люминесценции введённых в среде ск- $\mathrm{CO}_{2}$ $\mathrm{Nd}(\mathrm{Acac})_{3}$ и фенантролина соответствует полосам люминесценции чистого Phen (табл. 1). Это, очевидно, связано с большим сродством фенантролина (по сравнению c $\left.\mathrm{Nd}(\mathrm{Acac})_{3}\right)$ к ароматическому поликарбонату.

Следует подчеркнуть, что образование смешанных $\beta$-дикетонатов неодима в полимерных матрицах наблюдается только при импрегнации полимерных матриц в среде ск- $\mathrm{CO}_{2}$. Так, в табл. 1 приведены данные по положениям полос в спектре люминесценции экстракта, полученного выдерживанием в хлороформе плёнки ОУМ-5, импрегнированной $\mathrm{Nd}(\mathrm{Acac})_{3}$, а затем фенантролином. Спектр явно состоит из нескольких 

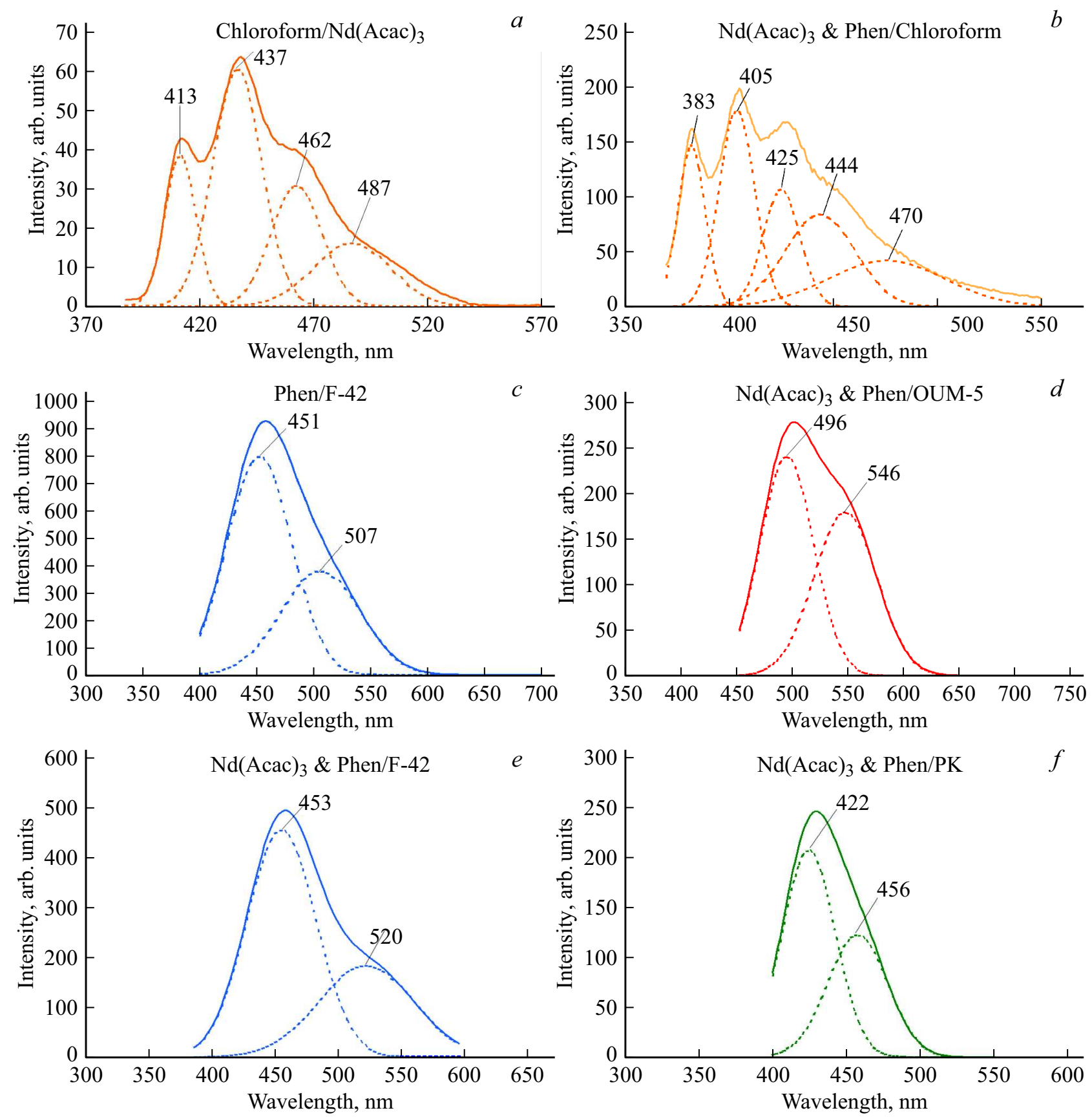

Рис. 1. Спектры люминесценции полимеров, ск-импрегнированных фенантролином (для Ф-42 (F-42) $\lambda_{\text {возб }}=365 \mathrm{~nm}(c)$, для ОУМ-5 и ПК (РК) вид спектров схож со спектром, представленным для Ф-42 (F-42)), ск-импрегнированных $\mathrm{Nd}(\mathrm{Acac})_{3}$ и фенантролином (для ОУМ-5 $\lambda_{\text {возб }}=435 \mathrm{~nm}(d)$, для $\Phi-42(\mathrm{~F}-42) \lambda_{\text {возб }}=365 \mathrm{~nm}(e)$, для ПК $\left.(\mathrm{PK}) \lambda_{\text {возб }}=410 \mathrm{~nm}(f)\right)$, а также раствора $\mathrm{Nd}(\mathrm{Acac})_{3}$ $\left(\lambda_{\text {возб }}=380 \mathrm{~nm}\right)(a)$ и совместного раствора $\mathrm{Nd}(\mathrm{Acac})_{3}$ и фенантролина в хлороформе $\left(\lambda_{\text {возб }}=360 \mathrm{~nm}\right)(b)$.

накладывающихся друг на друга узких полос, положения максимумов которых совпадает с максимумами полос люминесценции совместного раствора $\mathrm{Nd}(\text { Aсас })_{3}$ и фенантролина в хлороформе (табл. 1). Исходя из этого можно сделать вывод, что разнолигандные системы $\mathrm{Nd}(\mathrm{Acac})_{3}$ и фенантролина, характеризующиеся батохромным смещением люминесценции относительно люминесценции систем $\mathrm{Nd}(\mathrm{Acac})_{3} /$ полимер, образуются только при участии полимерной матрицы.
Интересно отметить, что при проведении скимпрегнации полимеров $\mathrm{Nd}(\mathrm{Acac})_{3}$ и фенантролином, находящимися в реакторе в раздельных емкостях (массы навесок $\mathrm{Nd}(\mathrm{Acac})_{3}$ и фенантролина - $20 \mathrm{mg}$ ), системы $\mathrm{Nd}$ (Aсас) $)_{3} / \mathrm{Phen} /$ полимер, скорее всего, не образуются. В спектрах люминесценции импрегнированных таким способом полимеров преимущественно наблюдаются высокоинтенсивные полосы, относящиеся к люминесценции фенантролина, положение которых при этом 
перекрывается с положением низкоинтенсивных полос люминесценции $\mathrm{Nd}(\mathrm{Acac})_{3}$. При этом полос, которые можно было бы отнести к люминесценции разнолигандного комплекса, зарегистрировать не удалось. Скорее всего, сродство молекул фенантролина к полимерной матрице много больше, чем у ацетилацетоната неодима, из-за чего фенантролину энергетически более выгодно стабилизироваться в полимерной матрице.

\section{Люминесценция полимеров, содержащих $\mathrm{Nd}(\mathrm{Acac})_{3}$ и фенантролин и полученных альтернативными методами. Получить системы,} содержащие смешанные $\beta-\mathrm{Nd}(\mathrm{Acac})_{3}$ и фенантролина и проявляющие батохромно смещённую люминесценцию иными способами, кроме как импрегнацией в сксреде, не удалось. Было отмечено, что у раствора фенантролина в ацетилацетоне люминесценция не регистрируется, а в спектре люминесценции смеси $\mathrm{Nd}(\mathrm{Acac})_{3}$ и фенантролина, взятых в равномолярном соотношении $\left(1.2 \cdot 10^{-3} \mathrm{M}\right.$ для каждого компонента) в хлороформе, не наблюдается сдвигов относительно положения полос в спектре люминесценции $\mathrm{Nd}(\mathrm{Acac})_{3}$ в хлороформе, что свидетельствует об отсутствии комплексообразования в системе $\mathrm{Nd}(\mathrm{Acac})_{3} / \mathrm{Phen}$ в этих условиях.

Для плёнки $\Phi-42$, полученной испарением совместного раствора $\Phi-42, \mathrm{Nd}(\mathrm{Acac})_{3}$ и фенантролина в ацетоне, зарегистрированы спектры люминесценции, идентичные спектрам плёнки Ф-42, отлитой из совместного раствора $\Phi-42$ с $\mathrm{Nd}(\mathrm{Acac})_{3}$. Кроме того, была сделана попытка получения системы $\mathrm{Nd}(\mathrm{Acac})_{3} / \mathrm{Phen} /$ полимер (ОУМ-5, $\Phi-42$, ПК) пропиткой полимеров раствором, содержащим $\mathrm{Nd}(\mathrm{Acac})_{3}$ и Phen в равномолярном соотношении $\left(1.2 \cdot 10^{-3} \mathrm{M}\right.$ для каждого компонента). В спектрах люминесценции полученных образцов (выдержанных в органическом растворителе, содержащем $\mathrm{Nd}(\mathrm{Acac})_{3}$ и фенантролин) присутствовали полосы, соответствующие полосам люминесценции ацетилацетоната неодима и фенантролина, введённых в полимеры аналогичным методом. Однако полос люминесценции разнолигандного комплекса в таких образцах обнаружено не было.

Таким образом, полученные результаты свидетельствуют о том, что полимеры (ОУМ-5, Ф-42, ПК), содержащие смешанные $\beta$-дикетонаты неодима $\left(\mathrm{Nd}(\mathrm{Acac})_{3}(\mathrm{Phen})\right)$, стабилизированные фрагментами полимерной матрицы, можно получить только импрегнацией матриц компонентами в среде ск- $\mathrm{CO}_{2}$.

\section{Процессы термоокислительной деструкции ск-импрегнированных полимеров}

Для подтверждения образования смешанных $\beta$-дикетонатов в полимерных матрицах в условиях ск-среды был проведён дифференциально-термический анализ (ДТА) исходных полимеров, полимеров, импрегнированных $\mathrm{Nd}(\text { Acac })_{3}$, фенантролином, а также $\mathrm{Nd}(\text { Acac })_{3}$ и фенантролином. В качестве иллюстрации здесь приведены
Таблица 2. Кинетические параметры термоокислительной деструкции полимера ОУМ-5, содержащего $\mathrm{Nd}(\mathrm{Acac})_{3}$ и фенантролин, введённые различными методами

\begin{tabular}{|c|c|c|c|}
\hline $\begin{array}{l}\text { Наименование } \\
\text { образца }\end{array}$ & $\begin{array}{l}Q, \\
\mathrm{~J} / \mathrm{g}\end{array}$ & $\begin{array}{l}W_{\max } \\
\% / \min \end{array}$ & $\begin{array}{l}\text { Кокс при } \\
500^{\circ} \mathrm{C}, \%\end{array}$ \\
\hline ОУМ-5, исходный & 615 & 40 & 14 \\
\hline $\begin{array}{l}\text { ОУМ- } 5+\mathrm{Nd}(\text { Aсас })_{3}, \\
\text { ск-импрегнация }\end{array}$ & 1261 & 43 & 1 \\
\hline $\begin{array}{l}\text { ОУМ-5 }+\mathrm{Nd}(\text { Aсас })_{3} \text {, } \\
\text { пропитка в растворе }\end{array}$ & 1082 & 17 & 6 \\
\hline $\begin{array}{l}\text { ОУМ-5 + Phen, } \\
\text { ск-импрегнация }\end{array}$ & 614 & 12 & 11 \\
\hline $\begin{array}{l}\text { ОУМ-5 + Phen, } \\
\text { пропитка в растворе }\end{array}$ & 477 & 22 & 29 \\
\hline $\begin{array}{l}\text { ОУМ- } 5+\mathrm{Nd}(\text { Acac })_{3}+\text { Phen, } \\
\text { ск-импрегнация }\end{array}$ & 314 & 13 & 12 \\
\hline $\begin{array}{l}\text { ОУМ- } 5+\mathrm{Nd}(\text { Acac })_{3}+\text { Phen, } \\
\text { пропитка в растворе }\end{array}$ & 362 & 14 & 23 \\
\hline
\end{tabular}

Примечание. $Q, \mathrm{~J} / \mathrm{g}$ - суммарный тепловой эффект, сопровождающий ТОД, $W_{\max }, \% / \min$ - скорость потери массы.

результаты анализа для ОУМ-5, поскольку в этом полимере наблюдается наиболее значительные изменения спектра люминесценции при импрегнации ацетилацетонатом неодима и фенантролином.

\section{Термоокислительная деструкция ОУМ-5, ск- импрегнированного $\mathrm{Nd}(\mathrm{Acac})_{3}$ и фенантроли-} ном. Оказалось, что $\mathrm{Nd}(\mathrm{Acac})_{3}$, введенный в условиях ск- $\mathrm{CO}_{2}$ в матрицу ОУМ-5, проявляет каталитические свойства, ускоряя процесс ТОД, при этом мало меняя механизм процесса. Так, начало ТОД сдвигается в область более низких температур на $10-15^{\circ} \mathrm{C}$ по отношению к ТОД исходного, ничем не импрегнированного полимера (рис. 2, $a, b$, кривые 1 и 2), и несколько изменяется стадийность процесса ТОД. При этом более чем в 10 раз уменьшается количество коксового остатка после ТОД (табл. 2).

Фенантролин, введенный в ОУМ-5 в условиях ск$\mathrm{CO}_{2}$, в отличие от $\mathrm{Nd}(\mathrm{Acac})_{3}$ меняет механизм ТОД одновременно с повышением термостабильности полимера (рис. 2, $a, b$, кривые 1,3). В области температур $370-420^{\circ} \mathrm{C}$ появляются три стадии потери массы с максимумами скорости потери массы при 377, 394 и $405^{\circ} \mathrm{C}$, отсутствующие на кривых ТОД исходного ОУМ-5. Уменьшается более чем в 3 раза максимальная скорость потери массы $W_{\max }$ по сравнению со скоростью потери массы $W_{\max }$ при ТОД исходного ОУМ-5 (табл. 2). Также изменяется характер кривых тепловыделения (рис. 2, b, кривые 1,3). На кривых ДСК вместо одного экзотермического пика с максимумом при $387^{\circ} \mathrm{C}$ у исходного ОУМ-5 появляются три экзопика с 

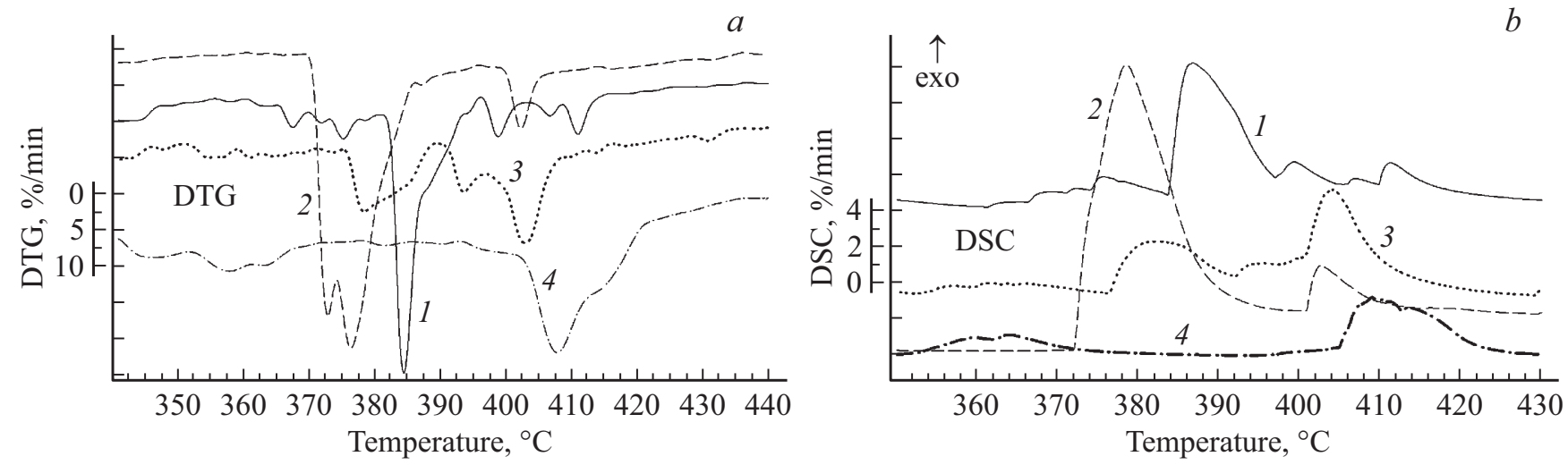

Рис. 2. Кривые дифференциального термического анализа при термоокислительной деструкции ОУМ-5, импрегнированного $\mathrm{Nd}(\mathrm{Acac})_{3}$ в условиях ск- $\mathrm{CO}_{2} . a-$ кривые ДТГ, $b-$ кривые ДСК, 1 - исходный ОУМ-5, 2 - ОУМ-5, ск-импрегнированный $\mathrm{Nd}(\mathrm{Acac})_{3}, 3$ - ОУМ-5, ск-импрегнированный Phen, 4 - ОУМ-5, ск-импрегнированный $\mathrm{Nd}(\mathrm{Acac})_{3}$ и Phen.
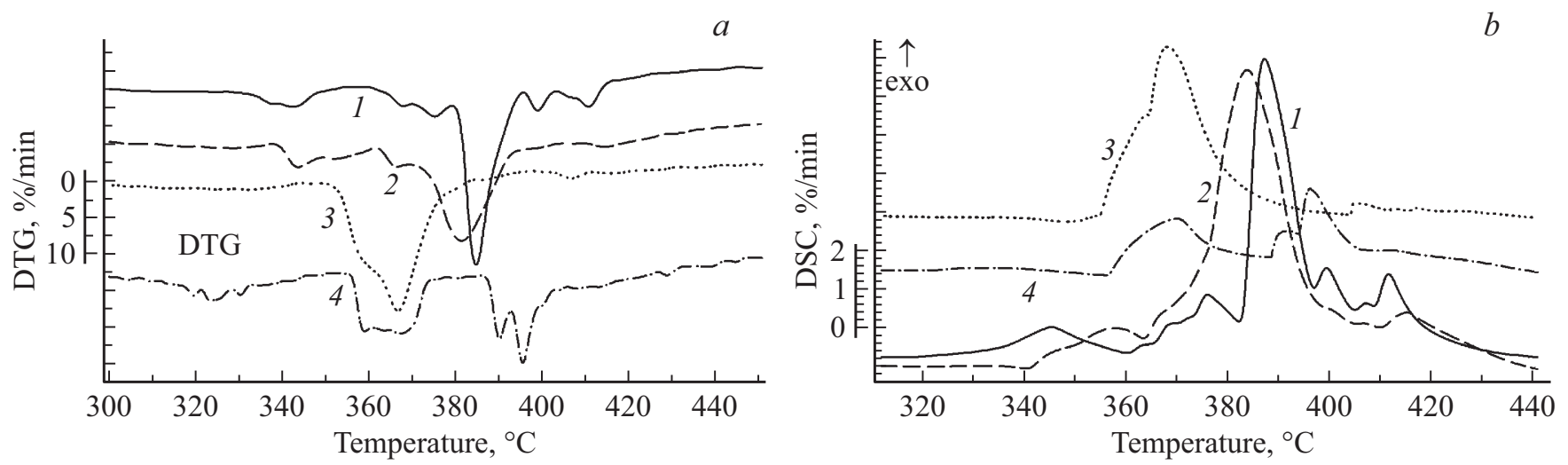

Рис. 3. Кривые дифференциального термического анализа при термоокислительной деструкции ОУМ-5, пропитанного $\mathrm{Nd}(\mathrm{Acac})_{3}$ в органическом растворителе. $a$ - кривые ДТГ, $b-$ кривые ДСК, 1 - исходный ОУМ-5, $2-$ ОУМ-5, пропитанный $\mathrm{Nd}(\mathrm{Acac})_{3}$, 3 - ОУМ-5, пропитанный Phen, 4 - ОУМ-5, пропитанный $\mathrm{Nd}(\mathrm{Acac})_{3}$ и фенантролином.

максимумами при 379, 395 и $406^{\circ} \mathrm{C}$. Такие изменения кривых ТГ и ДСК при термоокислительной деструкции ОУМ-5, очевидно, свидетельствуют о том, что в результате импрегнации ОУМ-5 фенантролином в условиях ск- $\mathrm{CO}_{2}$ происходит взаимодействие фенантролина с фрагментами полимерной матрицы ОУМ-5, что меняет механизм ТОД полимера и приводит к повышению термостабильности системы.

При совместном введении в ОУМ-5 $\mathrm{Nd}(\mathrm{Acac})_{3}$ и фенантролина в условиях ск- $\mathrm{CO}_{2}$ (соблюдая при этом определенную очередность введения) процессы ТОД тройной системы отличаются от соответствующих процессов систем ОУМ-5/ $\mathrm{Nd}(\mathrm{Acac})_{3}$ и ОУМ-5/Phen. На дифференциальных кривых ТОД образующейся системы не наблюдается отдельных четких стадий потери массы вплоть до $400^{\circ} \mathrm{C}$ (рис. 1, кривая 4). На кривых ТОД появляется высокотемпературная стадия $\left(400-425^{\circ} \mathrm{C}\right)$ с максимумом скорости потери массы при $408^{\circ} \mathrm{C}$, отсутствующая на кривых ДТГ систем ОУМ-5/ $\mathrm{Nd}(\text { Acac })_{3}$ и ОУМ/Phen. Эта стадия сопровождается существенно меньшим экзоэффектом $Q$, чем тепловые эффекты при деструкции всех рассмотренных выше систем (табл. 2). Такие изменения процесса ТОД - сдвиг основной стадии деструкции в высокотемпературную область, а также небольшая величина экзоэффекта $(Q=314 \mathrm{~J} / \mathrm{g})-$ свидетельствуют о более высокой термостойкости рассматриваемой тройной системы ОУМ-5/ $\mathrm{Nd}(\mathrm{Acac})_{3} / \mathrm{Phen}$ (по сравнению с соответствующими двойными системами), полученной при импрегнации ОУМ-5 указанными компонентами в условиях ск- $\mathrm{CO}_{2}$.

\section{Термоокислительная деструкция ОУМ-5, пропи- танного $\mathrm{Nd}(\mathrm{Acac})_{3}$ и фенантролином ,раствор- ным методом“. При введении $\mathrm{Nd}(\mathrm{Acac})_{3}$ „раствор-} ным методом“ (смотри экспериментальную часть) процессы ТОД, содержащие $\mathrm{Nd}(\text { Acac })_{3}$ и ОУМ-5, практически не отличаются от таких процессов для ОУМ-5, импрегнированного комплексом в ск-среде. Также, но в меньшей степени наблюдается каталитическая активность, связанная с влиянием комплекса $\mathrm{Nd}(\mathrm{Acac})_{3}$ (табл. 2). Не меняется стадийность процесса и величина коксового остатка (рис. $3, a, b$, кривая 2), сдвиг максиму- 
ма скорости потери массы в область более низких температур относительно исходного ОУМ-5 незначительный $\left(2-3^{\circ} \mathrm{C}\right.$, рис. $3, a$, кривые 1,2$)$ по сравнению со сдвигом $10-15^{\circ} \mathrm{C}$ у образцов ОУМ-5/ $\mathrm{Nd}(\mathrm{Acac})_{3}$, импрегнированных в условиях ск-СО $\mathrm{CO}_{2}$ (рис. 2, $a$, кривые 1,2 ).

При введении фенантролина в ОУМ-5 „растворным методом“ характер кривых ТОД полученной системы практически не изменяется по сравнению с исходным ОУМ-5, стадийность процесса сохраняется, наблюдается только сдвиг максимумов пиков тепловыделения и изменение скорости потери массы в более низкотемпературную область на $22^{\circ} \mathrm{C}$ с сохранением величины скорости. Полученные результаты демонстрируют, что при введении фенантролина из раствора в набухший ОУМ-5 Phen оказывает слабое воздействие на ТОД матрицы, что возможно, связано с более слабым взаимодействием Phen c матрицей по сравнению с импрегнацией в сксреде.

При введении в ОУМ-5 $\mathrm{Nd}(\mathrm{Acac})_{3}$ и фенантролина из раствора формируется система, термоокислительная деструкция которой сильно отличается от процесса ТОД системы ОУМ-5/ $\mathrm{Nd}(\mathrm{Acac})_{3} / \mathrm{Phen}$, полученной в условиях ск- $\mathrm{CO}_{2}$. Очевидно, в этих условиях не происходит формирования разнолигандного тройного комплекса ОУМ$5 / \mathrm{Nd}(\mathrm{Acac})_{3} /$ Phen, а каждый из компонентов самостоятельно взаимодействует с матрицей. В частности, на ДТГ имеется три четких пика. Первый пик в области температур $350-380^{\circ} \mathrm{C}$ характерен для процесса ТОД полимерной матрицы ОУМ-5, пропитанной через раствор только фенантролином (рис. 3, $а$, кривые 3,4). Следующие два пика находятся в более высокотемпературной области $\left(380-410^{\circ} \mathrm{C}\right)$ и, очевидно, отвечают за деструкцию фрагментов ОУМ-5, связанных с ацетилацетонатом неодима. При этом важно, что в данной системе $\mathrm{Nd}(\mathrm{Acac})_{3}$ не ускоряет термодеструкцию полимера. Таким образом, при „пропитке“ полимера ОУМ-5 раствором $\beta$-дикетоната неодима и фенантролина в органическом растворителе (в отличие от аналогичного введения компонентов в ск-среде) каждый компонент воздействует на ТОД матрицы по отдельности.

Все эти данные позволяют предположить, что при ск-импрегнации ОУМ-5, уже содержащего $\mathrm{Nd}(\mathrm{Acac})_{3}$, фенантролином, происходит замещение связанного с матрицей и оказывающего каталитический эффект на ТОД матрицы $\beta$-дикетоната неодима на фенантролин. При этом координационно ненасыщенный $\beta$-дикетонат связывается с матрицей через молекулы фенантролина в виде смешанного разнолигандного комплекса $\mathrm{Nd}(\mathrm{Acac})_{3} / \mathrm{Phen} /$ полимер, в котором уже не способен проявлять каталитическую активность. При этом альтернативными методами (в том числе пропиткой в растворе) тройные системы, содержащие $\beta$-дикетонат неодима, фенантролин и полимер, получить не удаётся. Эти предположения также подтверждаются изменением люминесцентных свойств образующихся систем.

\section{Выводы}

Синтезированы люминофорные разнолигандные комплексы ацетилацетоната неодима и фенантролина путём введения компонентов в полимерные матрицы в среде ск- $\mathrm{CO}_{2}$. Показано, что такие системы $\left(\mathrm{Nd}(\mathrm{Acac})_{3} / \mathrm{Phen} /\right.$ полимер) обладают люминесценцией, батохромно смещённой относительно полос люминесценции введенного в полимерные матрицы $\mathrm{Nd}(\mathrm{Acac})_{3}$, при этом величина сдвига зависит от природы матрицы, что свидетельствует об образовании нового смешанного $\beta$-дикетоната, стабилизированного фрагментами полимерных молекул. Для различных методов модификации полимеров (ск-импрегнация, отливка из раствора, пропитка в растворе) эффекта образования люминофорного разнолигандного $\beta$-дикетоната $\mathrm{Nd}(\mathrm{III})$ (где роль одного из лигандов играют макромолекулы полимера) удаётся добиться только при импрегнации в ск-среде. Дифференциально-термическим анализом ск-импрегнированных полимеров подтверждено формирование комплексом $\mathrm{Nd}(\mathrm{Acac})_{3}$ с фенантролином и полимером тройных систем в матрице ОУМ-5, а также отсутствие таких систем в полимере при введении компонентов из раствора.

\section{Финансирование работы}

Работа выполнена в рамках госзадания тема V. 46.14, № 0082-2014-0006 и при поддержке гранта РФФИ 1829-06019 мк с использованием оборудования Центра коллективного пользования „Анализ химических, биологических систем и природных материалов: люминесцентная спектроскопия““ (№ 506694).

\section{Конфликт интересов}

Авторы заявляют, что у них нет конфликта интересов.

\section{Список литературы}

[1] Kobayashi T., Nakatsuka S., Iwafuji T., Kuriki K., Imai N., Nakamoto T., Claude C.D., Sasaki K., Koike Y. // Appl. Phys. Lett. 1997. V. 71. P. 2421. doi 10.1063/1.120080

[2] Kido J., Okamoto Y. // Chem. Rev. 2002. V. 102. P. 2357-2368. doi 10.1021/cr010448y

[3] Taraeva A.Yu., Gerasimova V.I., Zavorotny Yu.S., Ribaltovskii $A$ O. // J. Appl. Spectr. 2007. V. 74. N 1. P. 42; Тараева А.Ю., Герасимова В.И., Заворотный Ю.С., Рыбалтовский А.О. // Журн. прикл. спектр. 2007. Т. 74. № 1. C. 42. doi 10.1007/s10812-007-0007-x

[4] Khramov R.N., Santalova I.M., Fakhranurova L.I., Simonova N.B., Manokhin A.A., Rzhevsky D.I., Murashev A.N. // Biophysics. 2010. V. 55. N 3. P. 447-452; Храмов Р.Н., Санталова И.М., Фахранурова Л.И., Манохин А.А., Симонова Н.Б., Ржсевский Д.И., Мурашев А.Н. // Биофизика. 2010. T. 55. B. 3. C. 507-513. doi 10.1134/S0006350910030164 
[5] Tarayeva A.Yu., Gerasimova V.I., Zavorotny Yu.S., Rybaltovsky A.O., Bagratashvili V.N. // SCF-TP. 2008. V. 3. N 1. Р. 59; Тараева А.Ю., Герасимова В.И., Заворотный Ю.С., Рыбалтовский А.О., Баграташвили В.Н. // СКФ-ТП. 2008. T. 3. № 1. C. 59-66.

[6] Sabbatini N., Guardigli M., Lehn J.-M. // Coord. Chem. Rev. 1993. V. 123. P. 201-228. doi 10.1016/0010-8545(93)85056-A

[7] Petrochenkova N.V., Petukhova M.V., Mirochnik A.G., Karasev V.E. // Rus. J. Coord. Chem. 2001. V. 27. N 9. P. 676-679. doi 10.1023/A:1017961808099

[8] Помогайло А.Д., Савостьянов В.С. // Успехи химии. 1991. T. 60. B. 7. C. $1513-1531$.

[9] Ivanitckiy A.E., Kolchev M.L., Butsenko E.S. // TSPU Bulletin. 2013. V. 8. Р. 136; Иваницкий А.Е., Колчев М.Л., Буиенко Е.С. // Вестник ТГПУ. 2013. Т. 8. С. 136.

[10] Gerasimova V.I., Antoshkov A.A., Zavorotny Yu.S., Rybaltovskii A.O., Lemenovskii D.A. // J. Lumin. 2013. V. 134. P. 339-344. doi 10.1016/j.jlumin.2012.08.024

[11] Kaplin V.S., Kopylov A.S., Ionov D.S., Yurasik G.A., Solov'eva A.B. // Rus. J. Phys. Chem. A. 2019. V. 93. N 8. P. 1268-1273; Каплин В.С., Копылов А.С., Ионов Д.С., Юрасик Г.А., Соловьёва А.Б. // Журн. физ. химии. 2019. T. 93. № 8. C. $1268-1273$. doi 10.1134/S0044453719080120

[12] Binnemans K. // Handbook on the Physics and Chemistry of Rare Earths. 2005. V. 35. Ch. 225. doi 10.1016/S01681273(05)35003-3

[13] Mirochnik A.G., Petrochenkova N.V., Karasev V.E. // Russ. Chem. Bull. 1997. V. 46. N 12. P. 2135. doi 10.1007/BF02495269

[14] Bunzli J.-C.G., Piguet C. // Chem. Soc. Rev. 2005. V. 34. P. $1048-1077$. doi 10.1039/b406082m

[15] Ermolaev V.L., Sveshnikova E.B., Bodunov E.N. // Phys.-Usp. 1996. V. 39. P. 261-282. doi 10.1070/PU1996v039n03ABEH000137

[16] de Sa G.F., Malta O.L., de Mello Donega C., Simas A.M., Longo R.L., Santa-Cruz P.A., da Silva Jr. E.F. // Coord. Chem. Rev. 2000. V. 196. P. 165-195. doi 10.1016/S00108545(99)00054-5 